\title{
Terrestrial arthropods from tree canopies in the Pantanal of Mato Grosso, Brazil
}

\author{
Marinêz Isaac Marques ${ }^{1}$, Joachim Adis², Geane Brizzola dos Santos ${ }^{3} \&$ Leandro Dênis Battirola ${ }^{3}$
}

\begin{abstract}
${ }^{1}$ Departamento de Biologia e Zoologia, Instituto de Biociências, Universidade Federal de Mato Grosso, Av. Fernando Correa da Costa, s/n, Coxipó, 78060-900, Cuiabá-MT, Brasil.m.marque@terra.com.br

${ }^{2}$ Max-Planck-Institute for Limnology, Tropical Ecology Working Group, Postfach 165, D-24302 Plön, Germany. adis@mpil-ploen.mpg.de ${ }^{3}$ Departamento de Zoologia, Universidade Federal do Paraná, Programa de Pós-Graduação em Ciências Biológicas (Entomologia), Caixa Postal 19030, 81531-980, Curitiba-PR, Brasil. gbrizola@yahoo.com; ldbattirola@uol.com.br
\end{abstract}

\begin{abstract}
Terrestrial arthropods from tree canopies in the Pantanal of Mato Grosso, Brazil. This study represents a contribution to the knowledge of the diversity of arthropods associated to the canopy of Vochysia divergens Pohl (Vochysiaceae). Three trees individuals were sampled during two seasonal periods in this region: a) by spraying one tree canopy during high water (February); b) by fogging two tree canopies during low water (September/October). The 15,744 arthropods $\left(183.2 \pm 38.9\right.$ individuals $\left./ \mathrm{m}^{2}\right)$ obtained from all three trees $\left(86 \mathrm{~m}^{2}\right)$ represented 20 taxonomic orders, $87.1 \%$ were Insecta, and $12.9 \%$ Arachnida. The dominant groups were Hymenoptera $\left(48.5 \% ; 88.9\right.$ individuals $\left./ \mathrm{m}^{2}\right)$, mostly Formicidae $\left(44.5 \% ; 81.4\right.$ individuals $\left./ \mathrm{m}^{2}\right)$, followed by Coleoptera $\left(14.0 \% ; 25.5\right.$ individuals $\left./ \mathrm{m}^{2}\right)$ and Araneae $(10.2 \%$; 19.5 individuals $/ \mathrm{m}^{2}$ ), together representing $62.5 \%$ of the total catch. Fourteen $(70 \%)$ of all orders occurred on three trees. Dermaptera, Isoptera, Neuroptera, Odonata, Plecoptera and Trichoptera were collected from only one tree. Of the total, 2,197 adult Coleoptera collected $\left(25.5 \pm 11.3\right.$ individuals $\left./ \mathrm{m}^{2}\right), 99 \%$ were assigned to 32 families and 256 morphospecies. Nitidulidae ( $17.9 \%$ of the total catch; 4.6 individuals $\left./ \mathrm{m}^{2}\right)$, Anobiidae $\left(16.7 \% ; 4.3\right.$ individuals $\left./ \mathrm{m}^{2}\right)$, Curculionidae $\left(13.2 \% ; 3.4\right.$ individuals $\left./ \mathrm{m}^{2}\right)$ and Meloidae $\left(11.4 \% ; 2.9\right.$ individuals $\left./ \mathrm{m}^{2}\right)$ dominated. The communitiy of adult Coleoptera on $V$. divergens indicated a dominance of herbivores ( $37.8 \%$ of the total catch, $127 \mathrm{spp}$.) and predators $(35.2 \%, 82 \mathrm{spp}$.$) , followed by saprophages (16.2 \%, 32 \mathrm{spp}$.$) and fungivores (10.8 \%, 15 \mathrm{spp}$.$) . The influence of the flood$ pulse on the community of arboreal arthropods in $V$. divergens is indicated by the seasonal variation in evaluated groups, causing changes in their structure and composition.
\end{abstract}

KEYWORDS. Arthropods; canopy; diversity; Pantanal.

RESUMO. Artrópodes terrestres associados a copas de árvores no Pantanal de Mato Grosso, Brasil. Este estudo representa uma contribuição ao conhecimento da diversidade de artrópodes associados à copa de Vochysia divergens Pohl (Vochysiaceae). Três indivíduos foram amostrados durante dois períodos sazonais, um durante a cheia (árvore A: fevereiro) utilizando-se o método de pulverização com inseticida e dois durante a seca (árvore B: setembro, C: outubro), empregandose a termonebulização. Um total de 15744 artrópodes $\left(183,2 \pm 38,9\right.$ individuos $\left./ \mathrm{m}^{2}\right)$ foram obtidos em $86 \mathrm{~m}^{2}$ de área representando 20 ordens taxonômicas, $87,1 \%$ Insecta e 12,9\% Arachnida. O grupo dominante foi Hymenoptera (48,5\%; 88,9 individuos $\left./ \mathrm{m}^{2}\right)$, a maioria Formicidae $\left(44,5 \% ; 81,4\right.$ individuos $\left./ \mathrm{m}^{2}\right)$, seguido por Coleoptera $\left(14,0 \% ; 25,5\right.$ individuos $\left./ \mathrm{m}^{2}\right)$ e Araneae $\left(10,2 \% ; 19,5\right.$ individuos $\left./ \mathrm{m}^{2}\right)$, que representaram $62,5 \%$ do total coletado. Com relação a freqüência, 14 de todas as ordens $(70 \%)$ ocorreram nas tres árvores. Dermaptera, Isoptera, Neuroptera, Odonata, Plecoptera e Trichoptera foram coletadas em uma única árvore. Foram obtidos 2197 Coleoptera adultos $\left(25,5 \pm 11,3\right.$ indivíduos $\left./ \mathrm{m}^{2}\right)$, sendo $99 \%$ assinalados para 32 famílias e 256 morfoespécies. Nitidulidae $\left(17,9 \% ; 4,6\right.$ indivíduos $\left./ \mathrm{m}^{2}\right)$, Anobiidae $(16,7 \% ; 4,3$ indivíduos/ $\left.\mathrm{m}^{2}\right)$, Curculionidae $\left(13,2 \% ; 3,4\right.$ indivíduos $\left./ \mathrm{m}^{2}\right)$ e Meloidae $\left(11,4 \% ; 2,9\right.$ indivíduos $\left./ \mathrm{m}^{2}\right)$ foram dominantes. Os Coleoptera adultos associados à copa de $V$. divergens indicam dominancia de herbívoros $(37,8 \%$ do total coletado, $127 \mathrm{spp}$.) e predadores $(35,2 \%, 82 \mathrm{spp}$.$) , seguidos por saprófagos (16,2\%, 32 \mathrm{spp}$.) e fungívoros (10,8\%, 15 spp.). A influência do pulso de inundação sobre a comunidade de artrópodes arbóreos associados à $V$. divergens é indicada pela variação sazonal nos grupos avaliados, gerando mudanças em sua estrutura e composição ao longo dos períodos sazonais.

PALAVRAS-CHAVE. Artrópodes; copa; diversidade; Pantanal.

Terrestrial arthropods are important organisms with fundamental functions in natural ecosystems such as predation, pollination, and even with complex relations between species of vertebrates and invertebrates that evolved simultaneously (Jolivet 1992; Samways 1994). Despite this recognized importance, data on the biology and ecology of many groups are few, principally of those that inhabit environments of difficult access like canopies (Basset 2001).

Various techniques have been developed to reach the canopy and the use of insecticides is one of the most utilized, irrespective of specimens that are not collected like those hidden in crevices, under bark, and involuted or mining in leaves (Basset et al. 1997; Erwin 1989; Stork \& Hammond 1997). Studies in forests demonstrated the efficiency of this methodology to describe the characteristics of arboreal communities like patterns in species abundance, body size, biomass, guild structure, dominance, eveness, richness, endemism, mode of nutrition, and seasonality (Basset et al. 2003; Linsenmair et al. 2001; Stork et al. 1997).

In Brazil, these studies concentrated in the Amazonian region, investigating forests on terra firme and of floodplains (Adis 1997; Adis et al. 1984, 1998b; Erwin 1983a, b; Harada \& 
Adis 1997, 1998; Hurtado-Guerrero et al. 2003). In the Pantanal of Mato Grosso, some aspects such as the guild structure of insects, patterns of herbivory and diversity on Tabebuia aurea and $T$. ochraceae (Bignoniaceae) have been approached by Ribeiro \& Brown (1999).

The dynamic of perodical inundations defines the community structure of terrestrial arthropods that colonize floodplains (Adis \& Junk 2002). The composition of this community both in the soil and in tree canopies of the Pantanal is virtually unknown. To evaluate the impact of the flood pulse (Junk et al. 1989, Da Silva et al. 2001) on terrestrial arthropods, preliminary studies over the past five years have focussed on both the terrestrial and the aquatic phase (Adis et al. 2001; Marques et al. 2001; Santos et al. 2003). The results presented in this contribution on arthropod orders, on families and morphospecies of Coleoptera from the canopy of a typical forest type in this region and comparison with results from other inventories in the same area provide data and observations on which hypotheses can be made for more detailed ecological studies in the future.

\section{MATERIALAND METHODS}

Study area. The study was undertaken in 2000 in an area dominated by Vochysia divergens Pohl (Vochysiaceae), a typical tree species of the Pantanal of Mato Grosso, known as "cambará" that forms monodominant forest stands called "cambarazais" (Nascimento \& Nunes da Cunha 1989). The study area is located at the Retiro Novo farm, in the district of Pirizal, municipality of Nossa Senhora do Livramento, situated on the right bank of Cuiabá river and the left bank of Bento Gomes river $\left(16^{\circ} 15^{\prime} 12^{\prime \prime} \mathrm{S}, 56^{\circ} 22^{\prime} 12^{\prime \prime} \mathrm{W}\right)$. The study area is subjected to a rainy season from October to April and to annual flooding of $0.6-1.5 \mathrm{~m}$ height, generally between December and March.

Methods. Three individuals of $V$. divergens (Table I) with few or no epiphytes, nor flowers and fruits were sampled according to the criteria given in Adis et al. (1998a) during two seasonal periods in the Pantanal of Mato Grosso: a) by spraying one tree canopy (A) during high water (February: aquatic phase, forest inundated); b) by fogging two tree canopies (B, C) during low water (September/October: terrestrial phase, forest not inundated).

To collect the arthropods, 22-33 funnel-shaped trays $\left(1 \mathrm{~m}^{2}\right.$ in area) made of nylon were installed under the canopy with numbers (Table I) depending on the circumference of the tree crown. All collecting trays were individually numbered and mapped to indicate their position in the four quadrants (I-IV) assigned that related to the canopy range. Data from the two tree canopies fogged during low water were used to analyse the distribution pattern of arthropods (Figs. 1, 2).

The insecticide used, Lambdacialotrine $0.5 \%$, is a nonresidual synthetic pyrethrum that was diluted in diesel oil to $1 \%$ and applied from the ground to all parts of the canopy with an agricultural sprayer (Bomba Hatsuda Costal, type
Table I. Characteristics of $V$. divergens trees fogged in the inundation forest at Fazenda Retiro Novo.

\begin{tabular}{lccc}
\hline & Tree A & Tree B & Tree C \\
& $21 / \mathrm{II} / 2000$ & $29 / \mathrm{IX} / 2000$ & $01 / \mathrm{X} / 2000$ \\
& - high water & - low water & - low water \\
\hline Crown diameter & $11 \mathrm{~m}$ & $35 \mathrm{~m}$ & $33 \mathrm{~m}$ \\
Tree height & $15 \mathrm{~m}$ & $12 \mathrm{~m}$ & $16 \mathrm{~m}$ \\
Trunk diameter (dbh) & $0.48 \mathrm{~m}$ & $0.80 \mathrm{~m}$ & $0.68 \mathrm{~m}$ \\
No $^{\circ}$ of collecting trays & 22 & 31 & 33 \\
\hline
\end{tabular}

Pulverisador UBL, FP-4, JD22-2.T) (tree A) or a thermonebulizer Swing Fog SN50 (trees B, C).

The insecticide was applied to each tree canopy around 6:00 a.m. Arthropods intercepted on the collecting trays were collected twice. The first collection occurred two hours after fogging, a drop time recommended for falling arthropods (Adis et al. 1998a; Erwin 1983a; Stork \& Hammond 1997). Thereafter each tree was thoroughly shaken by means of ropes attached to its limbs, so that remaining arthropods in the tree canopy would fall onto the collecting trays. The second collection occurred two hours later.

The arthropod material was transported to and deposited at the Entomological Laboratory of the Institute of Biosciences at the Federal University of Mato Grosso in Cuiabá, sorted and identified to the level of orders. Adult Coleoptera were identified to family level (Lawrence et al. 1999), assigned to trophic guilds (Erwin 1983b; Hammond et al. 1996) and their respective morphospecies (recognizable taxonomic units) determined.

Diversity indices of Shannon-Wiener ( $\left.\mathrm{H}^{\prime}\right)$, eveness, richness of species of Margalef(R), using the natural logarithm (ln) as suggested by Magurran (1988), were used to evaluate species diversity of the Coleoptera community from three trees of $V$. divergens during two seasonal periods.

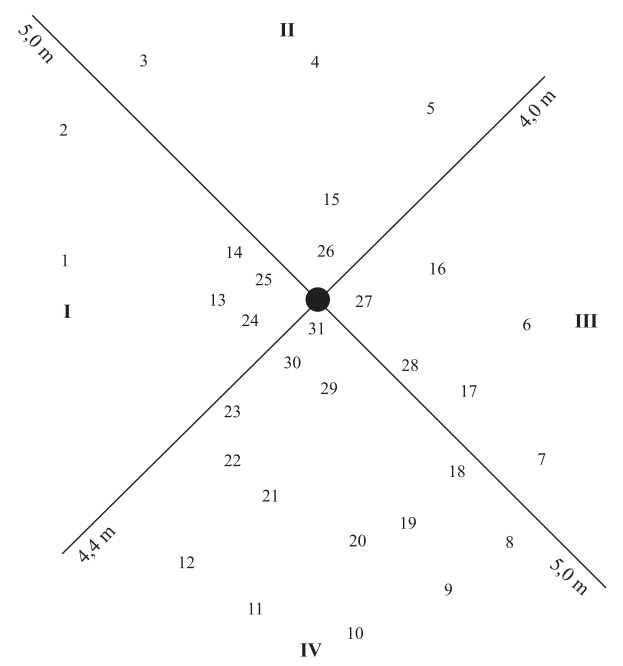

Fig. 1. Arrangement of collecting trays under the canopy of $V$. divergens during low water (tree B). I-IV = quadrants relating to canopy range. 


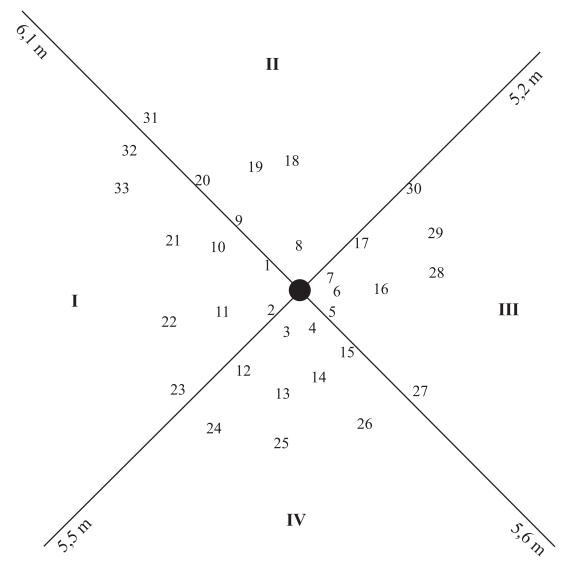

Fig. 2. Arrangement of collecting trays under the canopy of $V$. divergens during low water (tree $\mathrm{C}$ ). I-IV = quadrants relating to canopy range.

\section{RESULTSANDDISCUSSION}

Composition and dominance of groups. The 15,744 arthropods (183.2 \pm 38.9 individuals. $\left./ \mathrm{m}^{2}\right)$ obtained from three trees $\left(86 \mathrm{~m}^{2}\right)$ represented 20 taxonomic orders, $87.1 \%$ were Insecta, and $12.9 \%$ Arachnida.

The dominant groups (Fig. 3, Table II) were Hymenoptera $\left(48.5 \% ; 88.9\right.$ individuals $\left./ \mathrm{m}^{2}\right)$, mostly Formicidae $(44.5 \% ; 81.4$ individuals $\left./ \mathrm{m}^{2}\right)$, followed by Coleoptera $(14.0 \% ; 25.5$ individuals $/ \mathrm{m}^{2}$ ) and Araneae $\left(10.2 \% ; 19.5\right.$ individuals $\left./ \mathrm{m}^{2}\right)$, together representing $62.5 \%$ of the total catch. Fourteen $(70 \%)$ of all orders occurred on three trees. Dermaptera, Isoptera, Neuroptera, Odonata, Plecoptera and Trichoptera were collected from tree $\mathrm{C}$ only, during low water.

Santos et al. (2003) sprayed six canopies of the palm Attalea phalerata Mart. (Arecaceae; height 4-7 m) in this study area during low water (November/December 1999), using the same sampling method. The 17,188 arthropods $(238.7 \pm 80.6$ individuals $/ \mathrm{m}^{2}$ ) obtained represented 22 taxonomic orders, 90.8\% were Insecta, 9.1\% Arachnida, and 0.1\% Chilopoda. Coleoptera $\left(27.4 \% ; 65.5\right.$ individuals $\left./ \mathrm{m}^{2}\right)$, Hymenoptera $(21.4 \%$; 51.1 individuals $\left./ \mathrm{m}^{2}\right)$, mostly Formicidae $(19.0 \% ; 45.3$ individuals $\left./ \mathrm{m}^{2}\right)$ and Collembola $\left(13.6 \% ; 32.4\right.$ individuals $\left./ \mathrm{m}^{2}\right)$ dominated (Fig. 4), together representing $62.4 \%$ of the total catch. Seventeen of all orders (77\%) occurred on all trees, except Dermaptera, Neuroptera, Mantodea, Odonata, Opiliones, and Chilopoda. The higher arthropod abundance obtained in comparison to $V$. divergens was due to a greater number of Coleoptera, Collembola, and Diptera $(50.0 \%$ of the total catch) (Figs. 3, 4). Groups with low abundance and frequency on $V$. divergens and $A$. phalerata are considered occasional visitors.

Arthropod abundances in inundation forests of Central Amazonia were lower in both the blackwater region (igapó: 61.6 individuals $/ \mathrm{m}^{2}$ ) and the whitewater region (várzea: 32,1 individuals $/ \mathrm{m}^{2}$ ) (Adis et al. 1984). Ants were the dominant group (43.4 and $52.2 \%$, respectively) on three trees ( 2 species) fogged in each forest type. However, in a second study with

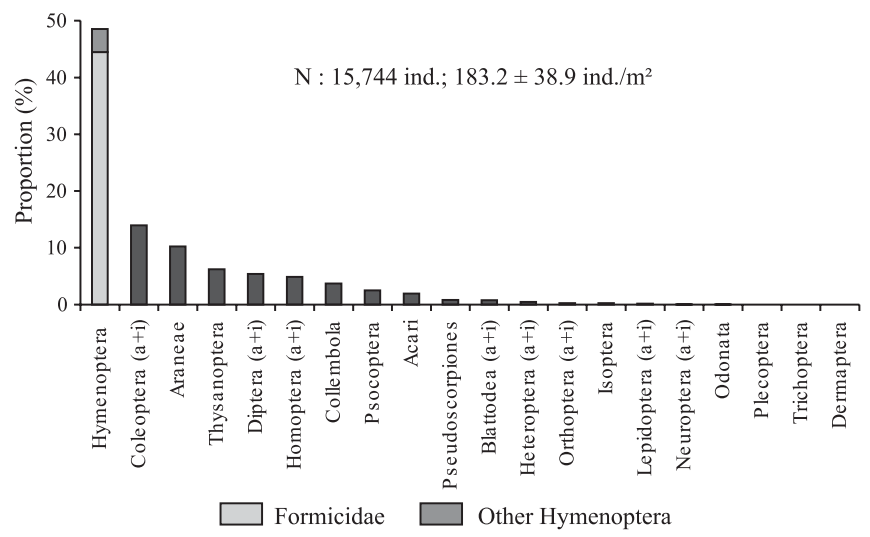

Fig. 3. Proportion (\%) of arthropods obtained from the canopy of three trees of $V$. divergens in decreasing rank of dominance; $\mathrm{a}+\mathrm{i}=$ adult+immatures, $\mathrm{N}=$ total number of arthropods collected.

four trees (4 species) fogged in the whitewater region (Adis 1997), abundances varied between 134 and 534 individuals/ $\mathrm{m}^{2}$. Adult Coleoptera (21\%), Formicidae (20\%) and adult Diptera $(13 \%)$ represented more than half of all arthropods obtained (23,689 individuals). The predominant taxa varied with the tree species sampled, being either Coleoptera (40.5\%), Formicidae (38.4\%), Homoptera (29.5\%) or Psocoptera (26.0\%). This demonstrates the necessity of broader studies like that on terra firme in Central Amazonia (Hurtado-Guerrero et al. 2003). Here Formicidae represented 51.7\% (143-877 individuals $\left./ \mathrm{m}^{2}\right)$

Table II. Total capture (Individuals), proportion (\%) and abundance (Individuals $/ \mathrm{m}^{2}$ ) with standard deviation (S.D.) of arthropod taxa obtained from the canopy of three trees of $V$. divergens; [ ] = immatures.

\begin{tabular}{|c|c|c|c|}
\hline Táxon & $\begin{array}{c}\text { Total } \\
\text { (individuals) }\end{array}$ & $\begin{array}{c}\text { Proportion } \\
(\%)\end{array}$ & $\begin{array}{c}\text { Individuals/ } \\
\mathrm{m}^{2} \pm \text { S.D. }\end{array}$ \\
\hline Acari & 304 & 1.9 & $3.5 \pm 5.5$ \\
\hline Araneae & 1608 & 10.2 & $19.5 \pm 16.2$ \\
\hline Blattodea & $122[77]$ & $0.8[0,5]$ & $1.4 \pm 0.5$ \\
\hline Coleoptera & $2197[20]$ & $14.0[0,1]$ & $25.5 \pm 11.3$ \\
\hline Collembola & 582 & 3.7 & $6.8 \pm 6.1$ \\
\hline Dermaptera & 1 & $<0.1$ & $<0.1 \pm 0.1$ \\
\hline Diptera & $847[17]$ & $5.4[0.1]$ & $9.8 \pm 3.7$ \\
\hline Heteroptera & $70[26]$ & $0.4[0.2]$ & $8.8 \pm 0.5$ \\
\hline Homoptera & $764[192]$ & $4.9[1.2]$ & $8.9 \pm 5.6$ \\
\hline Hymenoptera & 7642 & 48.5 & $88.9 \pm 42.8$ \\
\hline - Formicidae & $(7002)$ & $(44.5)$ & $(81.4 \pm 45.6)$ \\
\hline - Others & $(640)$ & $(4.0)$ & $(7.4 \pm 3.0)$ \\
\hline Isoptera & 34 & 0.2 & $0.4 \pm 0.6$ \\
\hline Lepidoptera & $27[14]$ & $0.2[0.1]$ & $0.3 \pm 0.2$ \\
\hline Neuroptera & 3 [2] & $<0.1[<0.1]$ & $<0.1 \pm 0.1$ \\
\hline Odonata & 2 & $<0.1$ & $<0.1 \pm 0.1$ \\
\hline Orthoptera & $41[9]$ & $0.3[0.1]$ & $0.5 \pm 0.4$ \\
\hline Plecoptera & 1 & $<0.1$ & $<0.1 \pm 0.1$ \\
\hline Pseudoscorpiones & 129 & 0.8 & $1.5 \pm 1.1$ \\
\hline Psocoptera & 392 & 2.5 & $4.6 \pm 5.9$ \\
\hline Thysanoptera & 977 & 6.2 & $11.4 \pm 9.2$ \\
\hline Trichoptera & 1 & $<0.1$ & $<0.1 \pm 0.1$ \\
\hline Total & 15,744 & 100.0 & $183.2 \pm 38.9$ \\
\hline
\end{tabular}




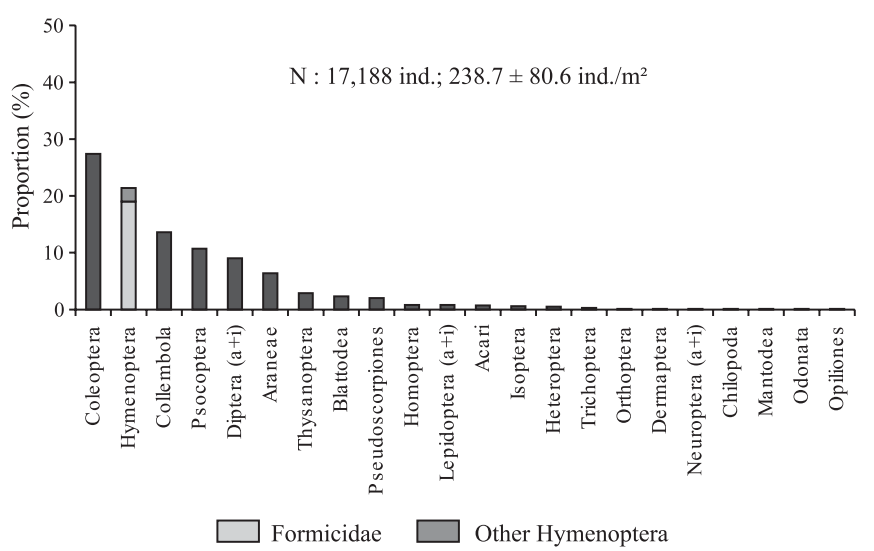

Fig. 4. Proportion (\%) of arthropods obtained from the canopy of six trees of $A$. phalerata in decreasing rank of dominance; $\mathrm{a}+\mathrm{i}=$ adults+immatures, $\mathrm{N}=$ total number of arthropods collected.

of all arthropods obtained by fumigating the canopy of 40 trees $\left(787 \mathrm{~m}^{2}\right)$ of nine tree species. Other dominant groups were Diptera (12.7\%), Psocoptera (5.9\%), and Collembola $(4.2 \%)$.

In the canopy of tropical forests, Formicidae generally represent the dominant taxa both in abundance and biomass (e.g., Adis et al. 1984; Basset 1991; Erwin 1983b; Floren \& Linsenmair 1997, 1998b; Harada \& Adis 1997, 1998; Stork 1988, 1991; Stork \& Brendell 1990, 1993; Tobin 1991; Wilson 1987). Its dominance with respect to biomass is partly explained by a greater body compared to terricolous ants (Tobin 1995). Soil inhabiting species are primarily predators and decomposers, whereas canopy species show a broad nutritional range using e.g., floral and extrafloral nectar, saps of plants and fruits, and exudates of arthropods and seeds (Davidson 1997; Tobin 1995).

Knockdown rates. Of the total arthropods sampled from $V$. divergens, $80.3 \%$ (146.4 individuals $\left./ \mathrm{m}^{2}\right)$ were obtained in the first two hours and the remaining 19.7\% (36.8 individuals $/ \mathrm{m}^{2}$ ) after the trees had been shaken. Formicidae were the dominant group in both samples (47.5 and $32.3 \%$, respectively). To the contrary of the first sample event, Araneae $(23.7 \%)$ was more abundant in the second sample than Coleoptera (11.7\%) (Fig. $5)$. During high water, $57.5 \%$ of the total spiders was obtained in the second sample. They supposedly hang on their spinning thread after dying and only fall with the tree being shaken.

On $A$. phalerata, $58.9 \%$ of the total arthropods were sampled in the first two hours, $37.6 \%$ after palms had been shaken, and only $3.5 \%$ after leaves were cut and rinsed with water (Santos et al. 2003). The discrepancy with $V$. divergens is attributed to the different leaf structure in palms and a trunk that accumulates organic matter.

When fogging 39 trees of Calophyllum brasiliense (Guttiferae) on terra firme in Central Amazonia, about $75 \%$ of all arthropods were obtained in the first two hours and the rest after trees had been shaken (Adis et al. 1997).

Capturing rates of trays. The distribution of collecting

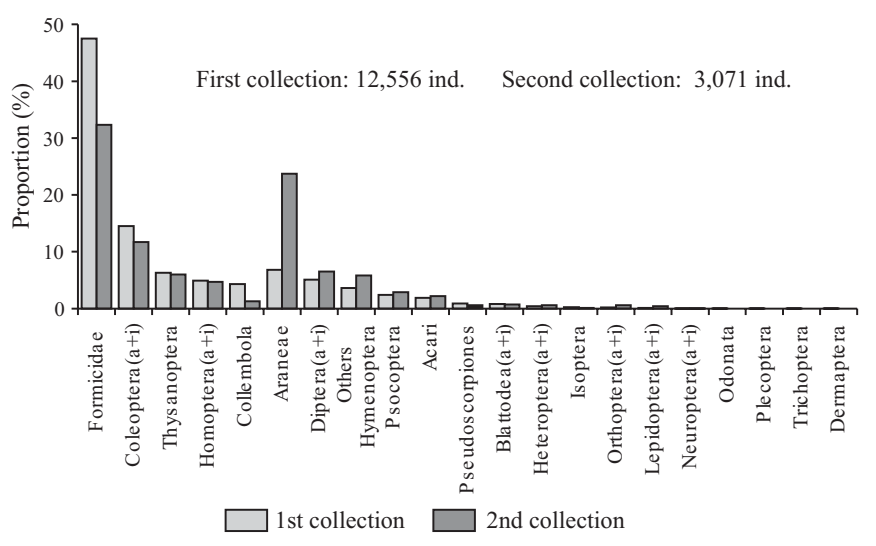

Fig. 5. Proportion (\%) of arthropods obtained per collecting event from three trees of $V$. divergens; $\mathrm{a}+\mathrm{i}=$ adults + immatures.

trays under each tree varied in dependence on the architecture of the tree crown and by avoiding crown gaps (Adis et al. 1998a).

For tree B (Fig. 1), the coefficient of variation (Zar 1974) for the number of individuals in each collecting tray was $76 \%$, with $60 \%$ of the fauna being represented by Formicidae, followed by Coleoptera, Thysanoptera, Araneae, Diptera and Collembola. The spacial distribution for the most representative groups in the canopy was evaluated by means of the four quadrants, revealing a higher abundance in trays close to the trunk and particularly in quadrant IV (Fig. 6). This distribution might possibly be related to a greater concentration of branches in this quadrant, permitting a greater area for migration and foraging, besides the greater availability of food, indicating in that way a heterogeneity in the canopy architecture. The great variation can also be explained by the aggregation pattern of some taxa, principally of ants. In adult Coleoptera, the Cocinellidae represented an aggregated pattern of distribution in one single tray (morphospecies 09 in funnel 1 of tree C) which might be related to the oviposition behaviour of these specimens.

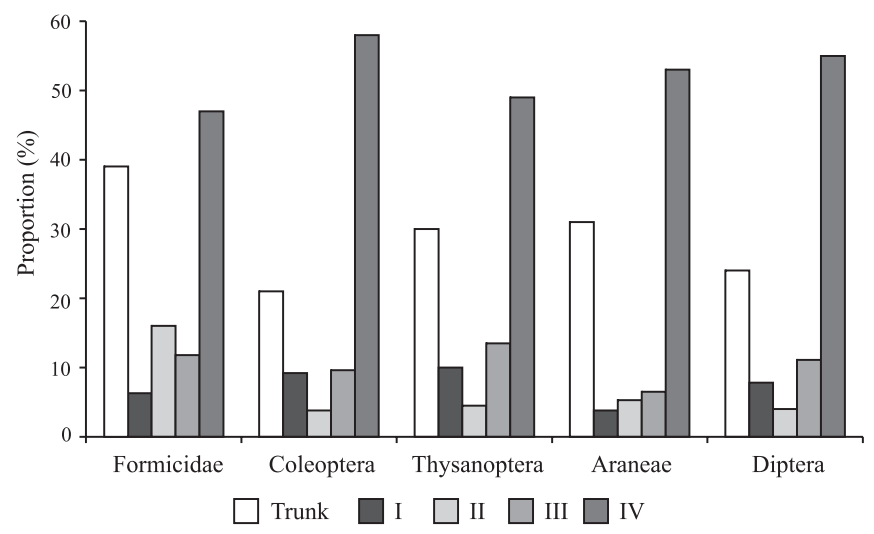

Fig. 6. Proportion (\%) of five arthropod groups obtained from $V$. divergens during low water (tree $\mathrm{B}$ ) in collecting trays close to the tree trunk and in the four quadrants assigned. 


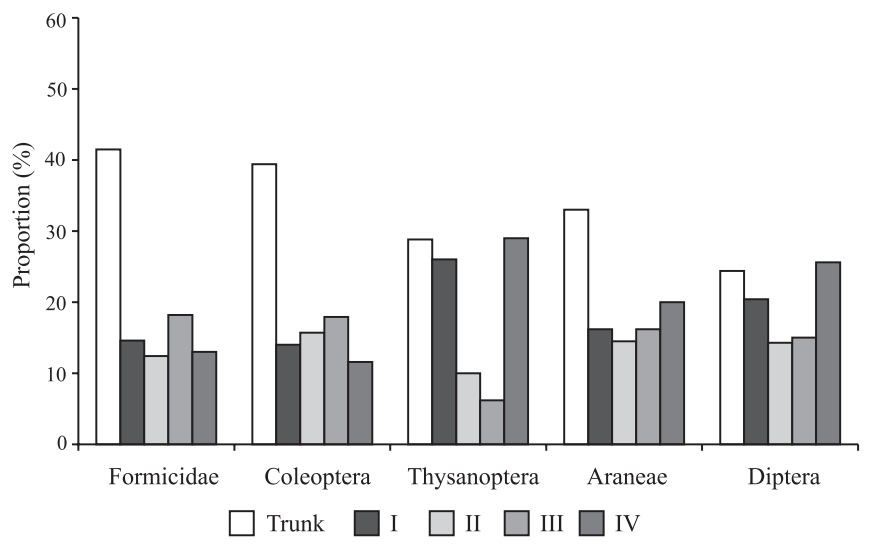

Fig. 7. Proportion (\%) of five arthropod groups obtained from $V$. divergens during high water (tree $\mathrm{C}$ ) in collecting trays close to the tree trunk and in the four quadrants assigned.

For tree C (Fig. 2), the coefficient of variation for the number of individuals in each collecting tray was $55 \%$, with $40 \%$ of the fauna being represented by Formicidae, Coleoptera, Collembola, Diptera, Araneae and Thysanoptera. The majority of these groups occurred in trays close to the trunk, a pattern found in tree B. However, distribution of groups between the four quadrants was more uniform (Fig. 7), indicating a more homogeneous canopy architecture.

Seasonality. Arthropod abundance of $181.3 \pm 65.2$ individuals $/ \mathrm{m}^{2}\left(11,604\right.$ individuals from $\left.64 \mathrm{~m}^{2}\right)$ during low water was comparable to that during high water. Formicidae $(49.6 \%$ of the total catch; 91.3 individuals $\left./ \mathrm{m}^{2}\right)$, Coleoptera $(11.4 \%$; 20.6 individuals $\left./ \mathrm{m}^{2}\right)$, Thysanoptera $(8.2 \% ; 15.1$ individuals/ $\mathrm{m}^{2}$ ) and Araneae $\left(6.4 \% ; 11.5\right.$ individuals $\left./ \mathrm{m}^{2}\right)$ dominated (Fig. 8).

During high water, $188.2 \pm 76.5$ individuals $/ \mathrm{m}^{2}(4,141$ individuals from $\left.22 \mathrm{~m}^{2}\right)$ were obtained, with Formicidae $(30.1 \%$ of the total catch; 56.6 individuals $\left./ \mathrm{m}^{2}\right)$, Coleoptera $(21.2 \%$; 39.9 individuals $\left./ \mathrm{m}^{2}\right)$, Araneae $\left(21.0 \% ; 39.5\right.$ individuals $\left./ \mathrm{m}^{2}\right)$ and Psocoptera $\left(6.4 \% ; 12.1\right.$ individuals $\left./ \mathrm{m}^{2}\right)$ being dominant (Fig. 8).

When spraying one tree of $V$. divergens (height $12 \mathrm{~m}$ ) in the study area during receding waters (June 1999: forest without inundation), Formicidae (44.0\% of the total catch; 19.2 $\left.\mathrm{ind} / \mathrm{m}^{2}\right)$ predominated as well, followed by Coleoptera $(14.1 \%$; 6.2 individuals $\left./ \mathrm{m}^{2}\right)$, Araneae $\left(14.0 \% ; 6.1 \%\right.$ individuals $\left./ \mathrm{m}^{2}\right)$ and Diptera (7.4\%; 3.2 individuals $/ \mathrm{m}^{2}$ ) (Marques et al. 2001).

Formicidae and Coleoptera, apart from being frequent, dominated independent of season, indicating that the canopy represents an important habitat. Some groups like Coleoptera, Acari, Araneae and Psocoptera showed greater abundances during high water, while Thysanoptera, Homoptera and Collembola during low water, thus indicating seasonality (Fig. 8). Basset (2001) considered Thysanoptera seasonal as they frequently occur on flowers of tropical trees, representing potential pollinators. Flowering of $V$. divergens occurs during low water and when $97.6 \%$ of the total Thysanoptera have been collected.

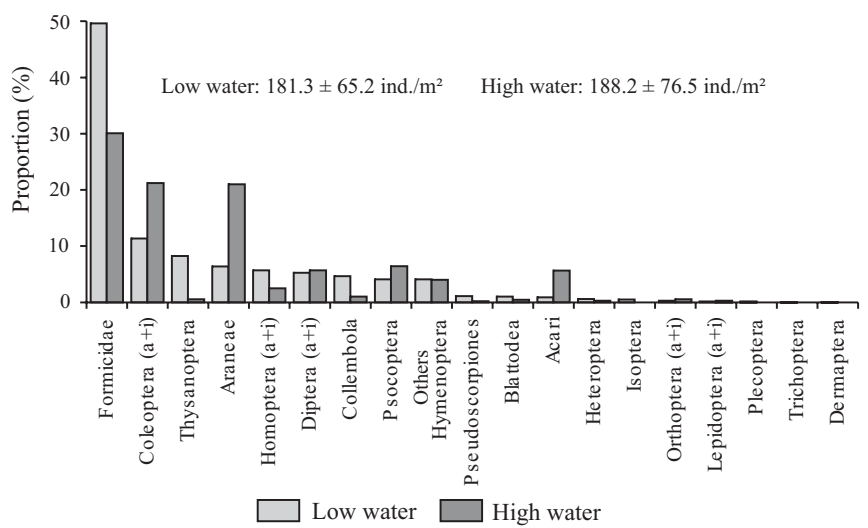

Fig. 8. Proportion (\%) of arthropods obtained from the canopy of $V$. divergens during low water (trees $\mathrm{B}, \mathrm{C})$ and high water (tree $\mathrm{A}) ; \mathrm{a}+\mathrm{i}=$ adults+immatures.

More than $85 \%$ of immature Blattodea, Homoptera and Heteroptera (307 individuals) were obtained during high water, indicating that the canopy is used by some groups for reproduction.

In Central Amazonian inundation forests, many terricolous species pass the aquatic phase on trees (Adis 1997). In the Pantanal this survival strategy was observed for Acromyrmex lundi carli (Myrmicinae). The ant species temporarily abandons its subterraneous nest and constructs a new one on limbs of Licania parvifolia (Chrysobalanaceae), above the water level (Adis et al. 2001). Araneae was the third most abundant group obtained with canopy fogging during high water which is possibly related to a migration from the soil to trees, too.

Adult Coleoptera: Families and morphospecies. Of the total 2,197 adult Coleoptera collected ( $25.5 \pm 11.3$ individuals $\left./ \mathrm{m}^{2}\right)$, $99 \%$ were assigned to 32 families and 256 morphospecies. Nitidulidae $\left(17.9 \%\right.$ of the total catch; 4.6 individuals $\left./ \mathrm{m}^{2}\right)$, Anobiidae (16.7\%; 4.3 individuals $\left./ \mathrm{m}^{2}\right)$, Curculionidae $(13.2 \%$;

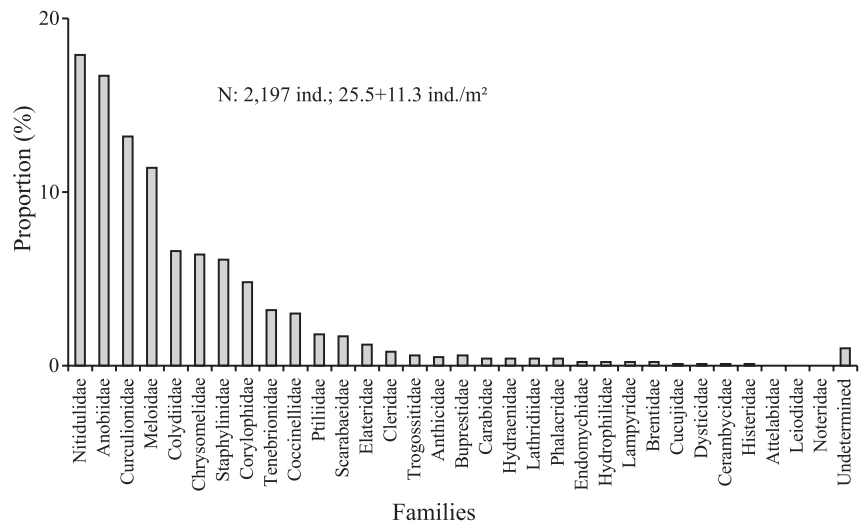

Fig. 9. Proportion (\%) of families of adult Coleoptera obtained from the canopy of three trees of $V$. divergens in decreasing rank of dominance; $\mathrm{a}+\mathrm{i}=$ adults + immatures, $\mathrm{N}=$ total number of arthropods collected. 
3.4 individuals $\left./ \mathrm{m}^{2}\right)$ and Meloidae $\left(11.4 \% ; 2.9\right.$ individuals $\left./ \mathrm{m}^{2}\right)$ dominated (Fig. 9, Tables III, IV and VII). Eighteen families occurred on three trees, ten on two trees, and four on one tree (Table III). Curculionidae (56 spp.), Chrysomelidae (34 spp.) and Staphylinidae (31 spp.) had the highest number of morphospecies (Table VII). Twenty-two morphospecies had $100 \%$ frequency, 65 occurred on two trees $(66.6 \%)$, and 169 on only one tree $(33.3 \%)$.

During receding waters, Marques et al. (2001) obtained 26 families of adult Coleoptera from one tree of $V$. divergens. Curculionidae (21.6\% of the total catch), Scolytidae (19.3\%), Elateridae (17.4\%) and Dryopidae (13.2\%) were dominant.

Of the total 4,715 adult Coleoptera ( $65.5 \pm 21.7$ individuals/ $\mathrm{m}^{2}$ ) collected from $A$. phalerata, 99\% were assigned to 44 families and 326 morphospecies. Tenebrionidae $(24.4 \%$ of the total catch; 16.0 individuals $\left./ \mathrm{m}^{2}\right)$, Curculionidae $(22 \% ; 14,7$ individuals $\left./ \mathrm{m}^{2}\right)$ and Carabidae $\left(10.8 \% ; 7.1\right.$ individuals $\left./ \mathrm{m}^{2}\right)$ dominated. The highest number of morphospecies was in Curculionidae (54 spp), Chrysomelidae (55 spp.) and Staphylinidae (44 spp.) (Santos et al. 2003) (Fig. 10, Tables III and IV).

Studies on arboreal Coleoptera communities in different regions of the tropics showed no predominance of the same families. Lathridiidae, Chrysomelidae, Staphylinidae, Apionidae and Curculionidae dominated in Uganda (Wagner 2000), whereas Chrysomelidae, Curculionidae and Staphylinidae on Borneo (Floren \& Linsenmair 1998b). Chrysomelidae and Curculionidae were more abundant in Amazonia of Peru (Farrell \& Erwin 1988), Bruchidae and Curculionidae in Venezuela (Davies et al. 1997). However, Chrysomelidae, Curculionidae and Staphylinidae represented the highest richness of species (Allison et al. 1993, 1997; Davies et al. 1997; Erwin 1983b; Erwin \& Scott 1980; Farrell\& Erwin 1988; Hammond et al. 1996, 1997; Wagner 2000), being valid for the Pantanal as well.

The number of individuals in Coleoptera inhabiting one tree of $V$. divergens $(732.3 \pm 125.0)$ was comparable to that of A. phalerata (785.8 \pm 260.1$)$. However, population density on $A$. phalerata was two times greater $(65.5 \pm 21.7$ vs. $25.5 \pm 11.3)$,

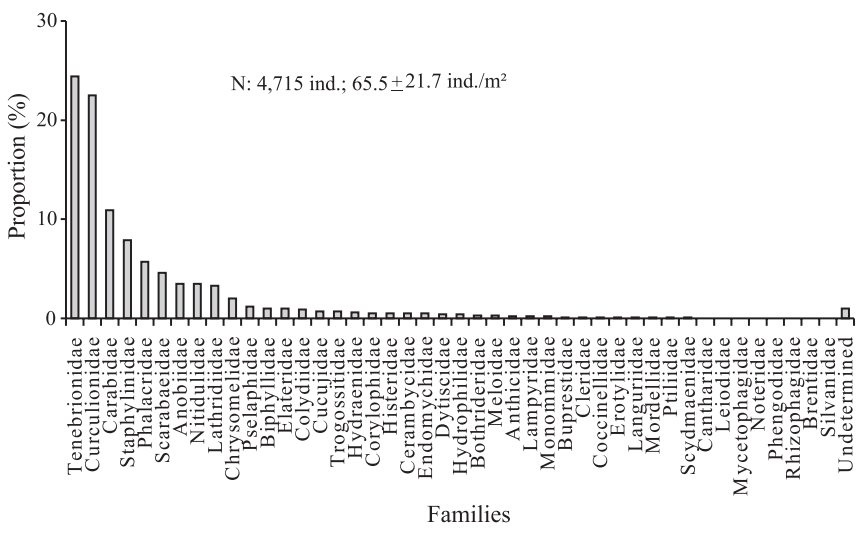

Fig. 10. Proportion (\%) of families of adult Coleoptera obtained from the canopy of six trees of $A$. phalerata in decreasing rank of dominance; $\mathrm{a}+\mathrm{i}=$ adults $+\mathrm{immatures,} \mathrm{N}=$ total number of arthropods collected.
Table III. Total capture (Individuals), proportion (\%) and frequency (\%) of adult Coleoptera families (Lawrence et al. 1999) obtained from the canopy of three trees of $V$. divergens and six trees of $A$. phalerata (Santos et al. 2003).

\begin{tabular}{|c|c|c|c|c|c|c|}
\hline & \multicolumn{3}{|c|}{ V. divergens } & \multicolumn{3}{|c|}{ A. phalerata } \\
\hline Family & $\begin{array}{l}\text { Total } \\
\text { (ind.) }\end{array}$ & $\begin{array}{c}\text { Proportion } \\
(\%)\end{array}$ & $\begin{array}{c}\text { Frequency } \\
(\%)\end{array}$ & $\begin{array}{l}\text { Total } \\
\text { (ind.) }\end{array}$ & $\begin{array}{c}\text { Proportion } \\
(\%)\end{array}$ & $\begin{array}{c}\text { Frequency } \\
(\%)\end{array}$ \\
\hline Anobiidae & 367 & 16.7 & 100 & 167 & 3.5 & 100 \\
\hline Anthicidae & 12 & 0.5 & 66.6 & 10 & 0.2 & 50 \\
\hline Attelabidae & 1 & $<0.1$ & 33.3 & - & - & - \\
\hline Biphyllidae & - & - & - & 45 & 1.0 & 100 \\
\hline Bothrideridae & - & - & - & 14 & 0.3 & 50 \\
\hline Brentidae & 12 & 0.5 & 66.6 & 10 & 0.2 & 50 \\
\hline Apioninae & (5) & $(0.2)$ & $(33.3)$ & (2) & $(<0.1)$ & (16.6) \\
\hline Buprestidae & 12 & 0.5 & 66.6 & 2 & $<0.1$ & 33.3 \\
\hline Cantharidae & - & - & - & 1 & $<0.1$ & 16.6 \\
\hline Carabidae & 9 & 0.4 & 33.3 & 511 & 10.8 & 100 \\
\hline Cerambycidae & 2 & 0.1 & 66.6 & 22 & 0.5 & 100 \\
\hline Chrysomelidae & 140 & 6.4 & 100 & 94 & 2.0 & 100 \\
\hline Bruchinae & (5) & $(0.2)$ & $(100)$ & (18) & $(0.4)$ & $(83.8)$ \\
\hline Cleridae & 18 & 0.8 & 100 & 6 & 0.1 & 50 \\
\hline Coccinellidae & 65 & 3.0 & 100 & 2 & $<0.1$ & 33.3 \\
\hline Colydiidae & 144 & 6.6 & 100 & 42 & 0.9 & 100 \\
\hline Corylophidae & 105 & 4.8 & 100 & 25 & 0.5 & 83.3 \\
\hline Cucujidae & 3 & 0.1 & 100 & 35 & 0.7 & 66.6 \\
\hline Curculionidae & 290 & 13.2 & 100 & 1057 & 22.4 & 100 \\
\hline Platypodinae & $(37)$ & $(1.7)$ & $(100)$ & $(5)$ & $(0.1)$ & $(50.0)$ \\
\hline Scolytinae & (74) & $(3.4)$ & $(100)$ & (13) & $(0.3)$ & (33.3) \\
\hline Dytiscidae & 3 & 0.1 & 66.6 & 18 & 0.4 & 50 \\
\hline Elateridae & 26 & 1.2 & 100 & 45 & 1.0 & 100 \\
\hline Endomychidae & 4 & 0.2 & 66.6 & 22 & 0.5 & 100 \\
\hline Erotylidae & - & - & - & 3 & 0.1 & 50 \\
\hline Histeridae & 2 & 0.1 & 66.6 & 23 & 0.5 & 83.3 \\
\hline Hydraenidae & 9 & 0.4 & 66.6 & 28 & 0.6 & 66.6 \\
\hline Hydrophilidae & 4 & 0.2 & 100 & 16 & 0.3 & 83.3 \\
\hline Lampyridae & 4 & 0.2 & 66.6 & 9 & 0.2 & 66.6 \\
\hline Languriidae & - & - & - & 4 & 0.1 & 33.3 \\
\hline Lathridiidae & 8 & 0.4 & 100 & 158 & 3.4 & 100 \\
\hline Leiodidae & 1 & $<0.1$ & 33.3 & 1 & $<0.1$ & 16.6 \\
\hline Meloidae & 250 & 11.4 & 100 & 13 & 0.3 & 83.3 \\
\hline Monommidae & - & - & - & 9 & 0.2 & 33.3 \\
\hline Mordellidae & - & - & - & 3 & 0.1 & 50 \\
\hline Mycetophagidae & - & - & - & 1 & $<0.1$ & 16.6 \\
\hline Nitidulidae & 393 & 17.9 & 100 & 165 & 3.5 & 100 \\
\hline Noteridae & 1 & $<0.1$ & 33.3 & 1 & $<0.1$ & 16.6 \\
\hline Phalacridae & 8 & 0.4 & 100 & 271 & 5.7 & 100 \\
\hline Phengodidae & - & - & - & 1 & $<0.1$ & 16.6 \\
\hline Ptiliidae & 39 & 1.8 & 66.6 & 4 & 0.1 & 50 \\
\hline Rhizophagidae & - & - & - & 1 & $<0.1$ & 16.6 \\
\hline Scarabaeidae & 30 & 1.4 & 100 & 216 & 4.6 & 100 \\
\hline Scydmaenidae & - & - & - & 8 & 0.2 & 33.3 \\
\hline Silvanidae & - & - & - & 1 & $<0.1$ & 16.6 \\
\hline Staphylinidae & 136 & 6.1 & 100 & 430 & 9.1 & 100 \\
\hline Pselaphinae & (4) & $(0.2)$ & $(33.3)$ & $(56)$ & $(1.2)$ & $(100.0)$ \\
\hline Tenebrionidae & 70 & 3.2 & 100 & 1149 & 24.4 & 100 \\
\hline Alleculinae & (1) & $(<0.1)$ & (33.3) & (69) & $(1.5)$ & $(100.0)$ \\
\hline Trogossitidae & 14 & 0.6 & 100 & 33 & 0.7 & 83.3 \\
\hline Undetermined & 22 & 1.0 & 100 & 47 & 1.0 & - \\
\hline Total & 2197 & 100 & 100 & 4715 & 100 & \\
\hline
\end{tabular}


Table IV. Density per tree (Individuals/tree) and abundance (Individuals $/ \mathrm{m}^{2}$ ) of families of adult Coleoptera (Lawrence et al. 1999) obtained from the canopy of three trees of $V$. divergens and six trees of $A$. phalerata (Santos et al. 2003) with their assigned trophic guilds. $\mathrm{H}=$ herbivores, $\mathrm{P}$ = predators, $\mathrm{F}=$ fungivores, $\mathrm{X}=$ xylophages, $\mathrm{S}=$ saprophages, $(\mathrm{)}=$ habit of nutrition in adults ranked secondary; S.D. $=$ standard deviation.

\begin{tabular}{|c|c|c|c|c|c|}
\hline Family & $\begin{array}{c}\text { V. divergens } \\
\text { ind./tree } \pm \text { S.D. }\end{array}$ & $\begin{array}{l}\text { A. phalerata } \\
\text { ind./tree } \pm \text { S.D. }\end{array}$ & $\begin{array}{l}\text { V. divergens } \\
\text { ind. } / \mathrm{m}^{2} \pm \text { S.D. }\end{array}$ & $\begin{array}{l}\text { A. phalerata } \\
\text { ind. } / \mathrm{m}^{2} \pm \text { S.D. }\end{array}$ & Guild \\
\hline Anobiidae & $122.3 \pm 91.2$ & $27.8 \pm 28.6$ & $4.3 \pm 3.2$ & $2.3 \pm 2.4$ & $\mathrm{H}(\mathrm{F})$ \\
\hline Anthicidae & $4.0 \pm 6.1$ & $1.7 \pm 2.7$ & $0.1 \pm 0.2$ & $0.1 \pm 0.2$ & $\mathrm{~S}$ \\
\hline Attelabidae & $0.3 \pm 0.6$ & - & $<0.1 \pm 0.0$ & - & $\mathrm{H}$ \\
\hline Biphyllidae & - & $7.5 \pm 4.6$ & - & $0.6 \pm 0.4$ & $\mathrm{~F}$ \\
\hline Bothrideridae & - & $2.3 \pm 3.4$ & - & $0.2 \pm 0.3$ & $\mathrm{P}$ \\
\hline Brentidae & $4.0 \pm 6.1$ & $1.7 \pm 2.7$ & $0.1 \pm 0.2$ & $0.1 \pm 0.2$ & $\mathrm{~S}$ \\
\hline Apioninae & $(1.7 \pm 2.9)$ & $(0.3 \pm 0.8)$ & $(0.1 \pm 0.1)$ & $(<0.1 \pm 0.1)$ & $\mathrm{H}$ \\
\hline Buprestidae & $4.0 \pm 6.1$ & $0.3 \pm 0.5$ & $0.1 \pm 0.2$ & $<0.1 \pm 0.0$ & $\mathrm{H}$ \\
\hline Cantharidae & - & $0.2 \pm 0.4$ & - & $<0.1 \pm 0.0$ & $\mathrm{H}$ \\
\hline Carabidae & $3.0 \pm 4.4$ & $85.2 \pm 64.7$ & $0.1 \pm 0.2$ & $7.1 \pm 5.4$ & $\mathrm{P}$ \\
\hline Cerambycidae & $0.7 \pm 0.6$ & $3.7 \pm 3.7$ & $<0.1 \pm 0.0$ & $0.3 \pm 0.3$ & $\mathrm{H}$ \\
\hline Chrysomelidae & $46.7 \pm 37.7$ & $31.3 \pm 5.51$ & $1.6 \pm 1.2$ & $1.3 \pm 0.3$ & $\mathrm{H}$ \\
\hline Bruchinae & $(1.7 \pm 1.2)$ & $(3.0 \pm 3.0)$ & $(0.1 \pm 0.0)$ & $(0.3 \pm 0.2)$ & $\mathrm{H}$ \\
\hline Cleridae & $6.0 \pm 3.6$ & $1.0 \pm 1.3$ & $0.2 \pm 0.1$ & $0.1 \pm 0.1$ & $\mathrm{P}$ \\
\hline Coccinellidae & $21.7 \pm 21.8$ & $7.0 \pm 7.2$ & $0.8 \pm 0.8$ & $0.6 \pm 0.6$ & $\mathrm{P}$ \\
\hline Colydiidae & $48.0 \pm 43.4$ & $0.3 \pm 0.5$ & $1.7 \pm 1.5$ & $<0.1 \pm 0.0$ & $\mathrm{P}(\mathrm{F})$ \\
\hline Corylophidae & $35.0 \pm 52.9$ & $4.2 \pm 5.3$ & $1.2 \pm 1.8$ & $0.3 \pm 0.4$ & $\mathrm{P}$ \\
\hline Cucujidae & $1.0 \pm 0.0$ & $5.8 \pm 7.7$ & $<0.1 \pm 0.0$ & $0.5 \pm 0.6$ & $\mathrm{P}(\mathrm{F})$ \\
\hline Curculionidae & $96.7 \pm 3.7$ & $173.2 \pm 61.9$ & $3.4 \pm 0.1$ & $14.7 \pm 13.5$ & $\mathrm{H}$ \\
\hline Platypodinae & $(12.3 \pm 14.7)$ & $(0.8 \pm 1.0)$ & $(0.4 \pm 0.5)$ & $(0.1 \pm 0.1)$ & $\mathrm{F}$ \\
\hline Scolytinae & $(24.7 \pm 13.3)$ & $(2.2 \pm 4.0)$ & $(0.9 \pm 0.5)$ & $(0.2 \pm 0.3)$ & $\mathrm{H}(\mathrm{F})$ \\
\hline Dytiscidae & $1.0 \pm 1.0$ & $3.0 \pm 5.1$ & $<0.1 \pm 0.0$ & $0.3 \pm 0.4$ & $\mathrm{P}$ \\
\hline Elateridae & $8.7 \pm 3.2$ & $7.5 \pm 1.8$ & $<0.1 \pm 0.0$ & $0.6 \pm 0.1$ & $\mathrm{H}(\mathrm{P})$ \\
\hline Endomychidae & $1.3 \pm 1.2$ & $3.7 \pm 2.4$ & $<0.1 \pm 0.0$ & $0.3 \pm 0.2$ & $\mathrm{~F}$ \\
\hline Erotylidae & - & $0.5 \pm 0.5$ & - & $<0.1 \pm 0.0$ & $\mathrm{~F}$ \\
\hline Histeridae & $0.7 \pm 0.6$ & $3.8 \pm 3.7$ & $<0.1 \pm 0.0$ & $0.3 \pm 0.3$ & $\mathrm{P}$ \\
\hline Hydraenidae & $3.0 \pm 4.4$ & $4.7 \pm 7.2$ & $0.1 \pm 0.2$ & $0.4 \pm 0.6$ & $\mathrm{P}$ \\
\hline Hydrophilidae & $1.3 \pm 0.6$ & $2.7 \pm 3.4$ & $<0.1 \pm 0.0$ & $0.2 \pm 0.3$ & $\mathrm{~S}$ \\
\hline Lampyridae & $1.3 \pm 1.5$ & $1.5 \pm 1.6$ & $<0.1 \pm 0.0$ & $0.1 \pm 0.1$ & $\mathrm{P}$ \\
\hline Languriidae & - & $0.7 \pm 1.0$ & - & $0.1 \pm 0.1$ & $\mathrm{H}$ \\
\hline Lathridiidae & $2.7 \pm 0.6$ & $26.3 \pm 21.1$ & $0.1 \pm 0.0$ & $2.2 \pm 1.8$ & $\mathrm{~F}$ \\
\hline Leiodidae & $0.3 \pm 0.6$ & $0.2 \pm 0.4$ & $<0.1 \pm 0.0$ & $<0.1 \pm 0.0$ & $\mathrm{~S}$ \\
\hline Meloidae & $83.3 \pm 64.9$ & $2.2 \pm 2.9$ & $2.9 \pm 2.3$ & $0.2 \pm 0.2$ & $\mathrm{H}$ \\
\hline Monommidae & - & $1.5 \pm 2.8$ & - & $0.1 \pm 0.2$ & $\mathrm{H}$ \\
\hline Mordellidae & - & $0.5 \pm 0.5$ & - & $<0.1 \pm 0.0$ & $\mathrm{H}$ \\
\hline Mycetophagidae & - & $0.2 \pm 0.4$ & - & $<0.1 \pm 0.0$ & $\mathrm{~F}$ \\
\hline Nitidulidae & $131.0 \pm 86.8$ & $27.5 \pm 31.4$ & $4.6 \pm 3.0$ & $2.3 \pm 2.6$ & $\mathrm{~S}$ \\
\hline Noteridae & $0.3 \pm 0.6$ & $0.2 \pm 0.4$ & $<0.1 \pm 0.0$ & $<0.1 \pm 0.0$ & $\mathrm{P}$ \\
\hline Phalacridae & $2.7 \pm 2.1$ & $45.2 \pm 30.3$ & $0.1 \pm 0.1$ & $3.8 \pm 2.5$ & $\mathrm{H}$ \\
\hline Phengodidae & - & $0.2 \pm 0.4$ & - & $<0.1 \pm 0.0$ & $\mathrm{P}$ \\
\hline Ptiliidae & $13.0 \pm 17.6$ & $0.7 \pm 0.8$ & $0.5 \pm 0.6$ & $0.1 \pm 0.0$ & $\mathrm{~S}(\mathrm{~F})$ \\
\hline Rhizophagidae & - & $0.2 \pm 0.4$ & - & $<0.0 \pm 0.0$ & $\mathrm{P}$ \\
\hline Scarabaeidae & $10.0 \pm 14.7$ & $36.0 \pm 35.8$ & $0.3 \pm 0.5$ & $3.0 \pm 3.0$ & $\mathrm{H}(\mathrm{S})$ \\
\hline Scydmaenidae & - & $1.3 \pm 2.4$ & - & $0.1 \pm 0.2$ & $\mathrm{P}$ \\
\hline Silvanidae & - & $0.2 \pm 0.4$ & - & $<0.1 \pm 0.0$ & $\mathrm{~F}$ \\
\hline Staphylinidae & $44.0 \pm 42.7$ & $62.3 \pm 34.7$ & $1.5 \pm 1.5$ & $5.2 \pm 2.9$ & $P(S, F)$ \\
\hline Pselaphinae & $1.3 \pm 2.3$ & $9.3 \pm 8.1$ & $<0.1 \pm 0.1$ & $0.8 \pm 0.7$ & $\mathrm{~F}$ \\
\hline Tenebrionidae & $24.6 \pm 30.4$ & $180.0 \pm 91.6$ & $0.8 \pm 1.1$ & $16.0 \pm 7.6$ & $\mathrm{~S}(\mathrm{~F})$ \\
\hline Alleculinae & $(0.3 \pm 0.6)$ & $(11.5 \pm 13.3)$ & $(<0.1 \pm 0.0)$ & $(1.0 \pm 1.1)$ & $\mathrm{H}$ \\
\hline Trogossitidae & $4.7 \pm 2.9$ & $5.5 \pm 7.1$ & $0.2 \pm 0.1$ & $0.5 \pm 0.6$ & $\mathrm{P}(\mathrm{S})$ \\
\hline Undetermined & $7.3 \pm 1.5$ & $7.8 \pm 2.2$ & $0.3 \pm 0.1$ & $0.7 \pm 0.2$ & - \\
\hline Total & $732.3 \pm 125.0$ & $785.8 \pm 260.1$ & $25.5 \pm 11.3$ & $65.5 \pm 21,7$ & - \\
\hline
\end{tabular}


Table V. Richness of morphospecies, number of individuals (N), and proportion (\%) of singletons of adult Coleoptera obtained from the canopy of three trees of $V$. divergens during high water (A) and low water $(\mathrm{B}, \mathrm{C})$.

\begin{tabular}{lccc}
\hline \multicolumn{1}{c}{ Tree } & $\mathrm{A}$ & $\mathrm{B}$ & $\mathrm{C}$ \\
\hline $\mathrm{N}^{\mathrm{o}}$ of morphospecies (S) & 138 & 118 & 109 \\
$\mathrm{~N}^{\mathrm{o}}$ of individuals (N) & 868 & 671 & 636 \\
Ratio (N/S) & 6.3 & 5.7 & 5.8 \\
Proportion of singletons (\%) & 44.2 & 54.2 & 55.0 \\
No of abundant morphospecies & 9 & 8 & 5 \\
\hline
\end{tabular}

indicating a less homogeneous distribution (Table IV). This is possibly related to the more complex leaf structure and accumulation of organic matter on the trunk in palms.

The composition of predominating families in adult Coleoptera between $A$. phalerata and $V$. divergens differed. Only Curculionidae was common on both (Figs. 9, 10). In this family, Celetes Schoenherr, 1836 was the dominant and exclusive genus on $A$. phalerata, suggesting a possible host specifity.

The diversity of adult Coleoptera on $V$. divergens was high during both low and high waters, showing a great number of species with low abundance and even distribution. Of the 256 identified morphospecies, 102 (39.8\%) were "singletons" (= one specimen collected in total), 47 (18.3\%) "doubletons" (= only two specimens collected), and $68(26.6 \%)$ with at least ten individuals obtained. Curculionidae (15 spp.), Staphylinidae (14 spp.), and Chrysomelidae (13 spp.) had the highest number of singletons. Abundance and richness of morphospecies was greater during high water (Fig. 11, Tables $\mathrm{V}$ and $\mathrm{VI}$ ).

Of the 326 morphospecies obtained from A. phalerata, $41.7 \%$ were singletons, $10.4 \%$ doubletons and $26.1 \%$ comprised less than 10 individuals (Santos et al. 2003). Chrysomelidae (25 spp.) and Staphylinidae (16 spp.) had the highest number of singletons.

Studies on adult Coleoptera in the canopy of different tropical and subtropical forests revealed that $40-50 \%$ of the species obtained represented singletons. In forests of Uganda, they accounted for $41.6 \%$ of the total catch (Wagner 2000) and on Papua New Guinea for 47.6 and 50.7\% (Allison et al. 1993, 1997). On Borneo singletons even represented $75 \%$ of the total species (Floren \& Linsenmair 1998a). In Venezuela almost $50 \%$ of the families were represented by fewer than five species (Davies et al. 1997). Considering the great occurrence

Table VI. Diversity indices and species richness of adult Coleoptera obtained from the canopy of three trees of $V$. divergens during high water $(\mathrm{A})$ and low water $(\mathrm{B}, \mathrm{C})$.

\begin{tabular}{lccc}
\hline \multicolumn{1}{c}{ Index } & Tree A & Tree B & Tree C \\
\hline Shannon-Wiener (H') & 3,89 & 3,65 & 3,46 \\
Evenness & 0,79 & 0,77 & 0,74 \\
Species richness - Margalef $(\mathrm{R})$ & 137,8 & 117,85 & 108,8 \\
$\mathrm{~N}^{0}$ of morphospecies & 138 & 118 & 109 \\
\hline
\end{tabular}

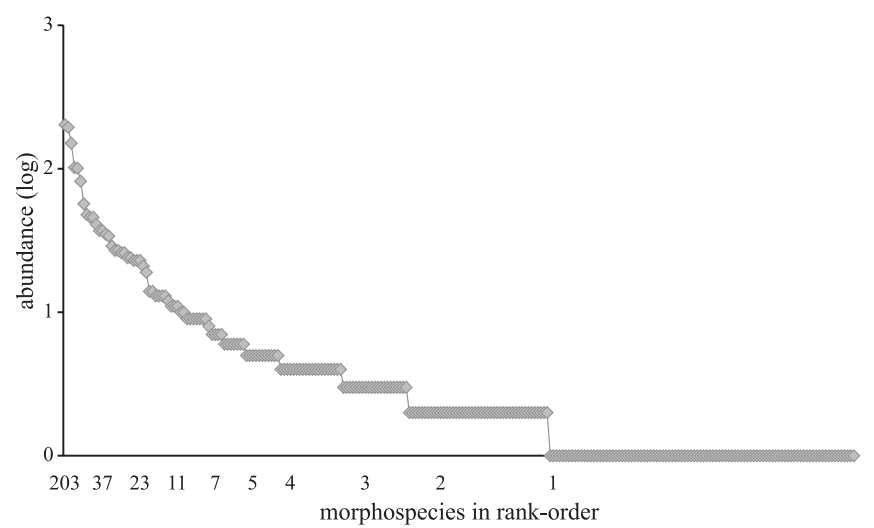

Fig. 11. Rank-abundance plot (log scale) of morphospecies of adult Coleoptera obtained from the canopy of three trees of $V$. divergens.

of rare species, an understanding of their ecological function in the canopy is needed (Basset 2001). The richness of herbivorous communities on plants and particularly of rare species can increase due to a constant influx of species originating from adjacent plants, named "mass effect" theory (Shmida \& Wilson 1985). This influx is important for insects in humid forests, where numerous plant species grow in close vicinity. However, it is possibly of less importance for the species richness on $A$. phalerata and $V$. divergens, considering that these trees cover great areas in the Pantanal of Mato Grosso as monodominant forest stands.

With regard to seasonality of adult Coleoptera on $V$. divergens, data showed that 5 families occurred in greater abundances during low water (Anobiidae, Meloidae, Curculionidae, Tenebrionidae, and Coccinellidae), whereas eight families were more abundant during high water (Nitidulidae, Corylophidae, Colydiidae, Staphylinidae, Chrysomelidae, Ptiliidae, Scarabaeidae, and Anthicidae). Abundances in the remaining families were similiar during both low and high waters (Fig. 12, Table VII). Of the total 256 morphospecies, the majority $(46.1 \%, 118 \mathrm{spp}$.) was obtained exclusively during low water, $29.3 \%$ (75 spp.) only during high water and 24,6\% (63 spp.) during both low and high waters (Fig. 13, Table VII). All morphospecies representing the Brentidae, Buprestidae, Dytiscidae, Endomychidae, Hydraenidae and Pselaphinae were obtained during low water. In other families such as Anobiidae and Tenebrionidae, 72.7\% of the morphospecies occurred solely during this period. Attelabidae, Leiodidae and Noteridae were represented by only one specimen each collected during high water (Table VII).

The seasonality of arboreal Coleoptera in humid forests, particularly of taxa with different trophic requirements, is poorly known (Basset 1991). In the Pantanal both seasonal changes in the host plant (e.g., flowering and fruiting, age, chemistry and savouriness of foliages) and the flood pulse certainly influence adults, in particular herbivores and their reproduction. For families with mainly terricolous larvae like Ptiliidae and Scarabeidae, data indicated that part of their adults pass the aquatic phase on trees. 
Table VII. Number of morphospecies of adult Coleoptera obtained exclusively from the canopy of $V$. divergens during low water (trees $\mathrm{B}$, C) or high water (tree A) and common during both low and high waters.

\begin{tabular}{|c|c|c|c|c|}
\hline Family & $\begin{array}{l}\text { Low } \\
\text { water }\end{array}$ & $\begin{array}{l}\text { High } \\
\text { water }\end{array}$ & $\begin{array}{c}\text { Low }+ \text { High } \\
\text { water }\end{array}$ & Total \\
\hline Anobiidae & 8 & 1 & 2 & 11 \\
\hline Anthicidae & 1 & 3 & - & 4 \\
\hline Attelabidae & - & 1 & - & 1 \\
\hline Brentidae & 4 & - & - & 5 \\
\hline Apioninae & (4) & $(-)$ & $(-)$ & (4) \\
\hline Buprestidae & 2 & - & - & 2 \\
\hline Carabidae & 1 & 1 & - & 2 \\
\hline Cerambycidae & 1 & 1 & - & 2 \\
\hline Chrysomelidae & 11 & 15 & 8 & 34 \\
\hline Bruchinae & $(-)$ & (2) & (1) & (3) \\
\hline Cleridae & 6 & - & 3 & 9 \\
\hline Coccinellidae & 6 & - & 5 & 11 \\
\hline Colydiidae & - & 1 & 3 & 4 \\
\hline Corylophidae & 1 & 1 & 2 & 4 \\
\hline Cucujidae & 2 & 2 & - & 4 \\
\hline Curculionidae & 23 & 20 & 13 & 56 \\
\hline Platypodinae & (1) & (3) & (2) & (6) \\
\hline Scolytinae & (5) & (4) & (3) & (12) \\
\hline Dityscidae & 3 & - & - & 3 \\
\hline Elateridae & 5 & 4 & - & 9 \\
\hline Endomychidae & 3 & - & - & 3 \\
\hline Histeridae & - & - & 1 & 1 \\
\hline Hydraenidae & 4 & - & - & 4 \\
\hline Hydrophilidae & 1 & - & 1 & 2 \\
\hline Lampyridae & 1 & - & 1 & 2 \\
\hline Lathridiidae & - & - & 2 & 2 \\
\hline Leiodidae & - & 1 & - & 1 \\
\hline Meloidae & 3 & & 3 & 6 \\
\hline Nitidulidae & 2 & 4 & 5 & 11 \\
\hline Noteridae & - & 1 & - & 1 \\
\hline Phalacridae & 3 & 1 & 1 & 5 \\
\hline Pitiliidae & - & 1 & 2 & 3 \\
\hline Scarabaeidae & 2 & 2 & 1 & 5 \\
\hline Staphylinidae & 11 & 13 & 7 & 31 \\
\hline Pselaphinae & 1 & - & - & 1 \\
\hline Tenebrionidae & 9 & 2 & 1 & 12 \\
\hline Alleculinae & (1) & $(-)$ & $(-)$ & (1) \\
\hline Trogossitidae & 4 & - & 2 & 6 \\
\hline Total & 118 & 75 & 63 & 256 \\
\hline
\end{tabular}

Trophic guilds. The communitiy of adult Coleoptera on $V$. divergens indicated a dominance of herbivores $(37.8 \%$ of the total catch, $127 \mathrm{spp}$.) and predators (35.2\%, $82 \mathrm{spp}$.), followed by saprophages (16.2\%, $32 \mathrm{spp}$.), and fungivores (10.8\%, 15 spp.) (Fig. 14). In herbivores, Anobiidae, Meloidae, Curculionidae and Chrysomelidae dominated, in predators Colydiidae, Staphylinidae and Coccinellidae, in saprophages Nitidulidae and Tenebrionidae, and in fungivores Lathridiidae and Endomychidae (Table IV).

The predominance of herbivores during low water $(64.1 \%$ of the total catch vs. $27.7 \%$ at high water) was due to Anobiidae (10 spp.) and Meloidae (6 spp.). The predominance of predators during high water $(33.1 \%$ vs. $9.6 \%$ at low water) was

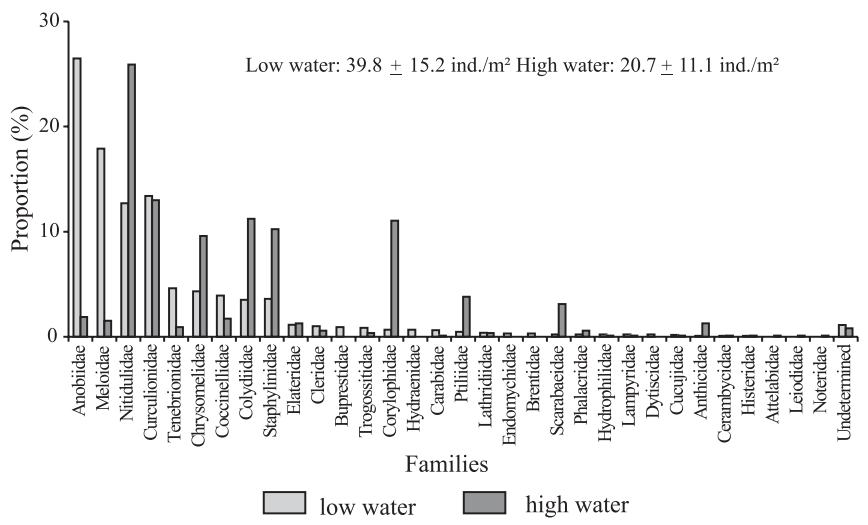

Fig. 12. Proportion (\%) of families of adult Coleoptera obtained from the canopy of $V$. divergens during low water (trees $\mathrm{B}, \mathrm{C}$ ) and high water (tree A); $\mathrm{a}+\mathrm{i}=$ adults + immatures.

due to Staphylinidae (20 spp.), Colydiidae (4 spp.) and Corylophidae (3 spp.) (Fig. 12, Table VII). Saprophages and fungivores showed similar abundances during both low and high waters. Herbivores also predominated during receding waters ( $42 \%$ of the total catch), followed by xylophages $(21 \%)$, saprophages $(21 \%)$, predators $(15 \%)$ and fungivores $(1 \%)$ (Marques et al. 2001).

In $A$. phalerata, herbivores ( $37.5 \%$ of the total catch) and predators $(35.4 \%)$ prevailed fungivores $(14.6 \%)$ and saprophages (12.5\%) as well (Fig. 15).

Studies of trophic guilds in other tropical regions indicated a dominance of herbivores or predators in the canopy. In Sulawesi and Australia predators dominated over fungivores, xylophages and herbivores (Hammond 1990; Hammond et al. 1996, 1997). In Venezuela herbivores predominated, followed by fungivores and predators (Davies et al. 1997). In Rwanda and Zaire herbivores and fungivores were more abundant (Wagner 1997). In Central Amazonia herbivores (74.4\%) from three inundation forests and one forest on terra firme predominated over predators (13.6\%), saprophages (9.3\%) and fungivores (2.7) (Erwin 1983b).

Evergreen and monodominant forests like $V$. divergens and A. phalerata in the Pantanal offer nutritional resources over the year. This might be an explication for the predominance of herbivores in their canopies. The greater abundance of

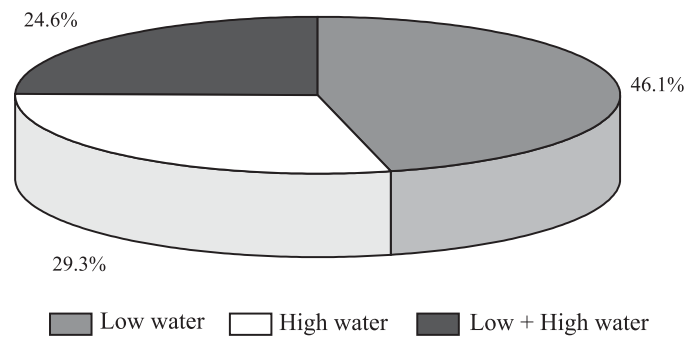

Fig. 13. Proportion (\%) of morphospecies in adult Coleoptera obtained during low or/and high water from the canopy of $V$. divergens. 


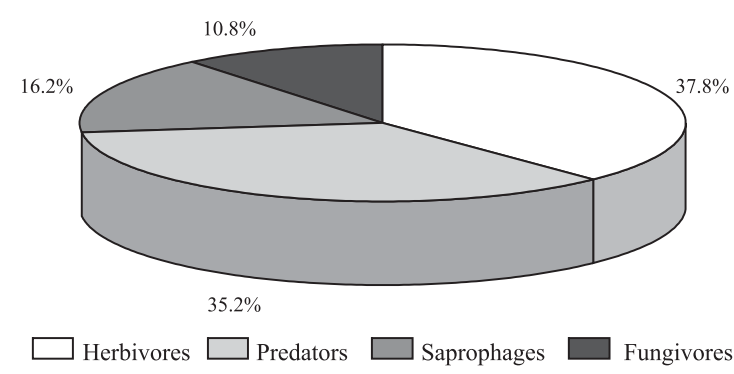

Fig. 14. Proportion (\%) of trophic guilds assigned to adult Coleoptera obtained from the canopy of three trees of $V$. divergens.

herbivores on $V$. divergens during low water (September/ October) may be related to the preceding flowering and fruiting of trees (July/August). The greater number of predators during high water may represent a reaction to the flood pulse due to a greater availability of prey, considering that terricolous arthropods use trees as refugium during the aquatic phase. Clarification of the function and life cycle of dominant morphospecies in the canopy both during low and high waters is mandatory for future studies.

\section{CONCLUSIONS}

The influence of the flood pulse on the community of arboreal arthropods in $V$. divergens is indicated by the seasonal variation in evaluated groups, causing changes in their structure and composition.

Formicidae was the predominating group both during low and high waters. Seasonality in Thysanoptera is attributed to flowering of the host plant during low water, and seasonality in Araneae to the temporary use of trees by terricolous species during high water.

The canopy represents a reproduction place for Blattodea, Homoptera and Heteroptera during high water.

Rare species (singletons, doubletons) cause the great diversity in adult Coleoptera. Distribution of species was even, however their abundance and richness was greater during high water. Five families were more abundant during low water (above all Nitidulidae), and nine families during high water (above all Anobiidae). Herbivores and predators were the dominating trophic groups. Predominance of predators during high water is attributed to the flood pulse, that of herbivores during low water to seasonal changes in the host plant.

Acknowledgements. This study results from the scientific cooperation between the Universidade Federal de Mato Grosso (UFMT) and the Max-Planck-Institut für Limnologie in Plön, Germany (SHIFT Program - Studies of Human Impact on Forests and Floodplains in the Tropics), financed by the Bundesministerium für Bildung, Wissenschaft, Forschung und Technologie (BMBF), the Conselho Nacional de Pesquisa e Desenvolvimento Tecnólogico ( $\mathrm{CNPq})$, and the Instituto Brasileiro de Meio Ambiente e Recursos Naturais Renováveis (IBAMA). We thank Dr. Terry L. Erwin, Smithsonian Institution, Washington, D.C., for valuable comments. The National Health Foundation (FNS-Cuiabá, Mato Grosso) is thanked for putting the sprayer at our disposal for sampling activities. We thank the technicians Francisco de Assis

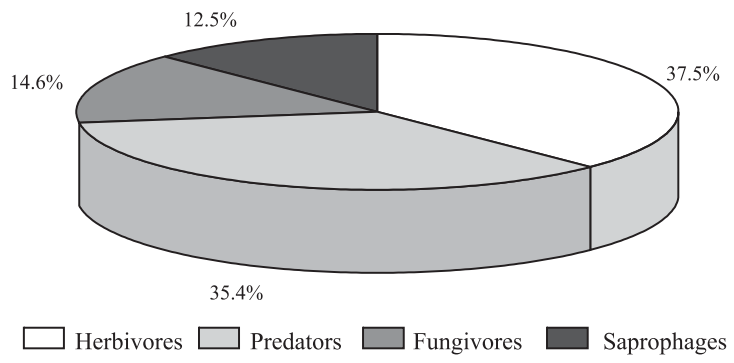

Fig. 15. Proportion (\%) of trophic guilds assigned to adult Coleoptera obtained from the canopy of six trees of A. phalerata.

Gonçalves Rondon (UFMT), Benedito Antonio Martins (FNS) and the students of the Entomological Laboratory of the Institute of Biosciences at UFMT for their help during field activities, in particular Ana Maria Figueiredo and Alessandra Gomes de Moraes.

\section{REFERENCES}

Adis, J. 1997. Terrestrial invertebrates: survival strategies, group spectrum, dominance and activity patterns, p. 299-317. In: W. J. Junk (ed.). The Central Amazon Floodplain. Ecological Studies. Berlin, Springer, 525 p.

Adis, J. \& W. J. Junk. 2002. Terrestrial invertebrates inhabiting lowland river floodplains of Central Amazonia and Central Europe: a review. Freshwater Biology 47: 711-731.

Adis, J.; D. Lubin \& G. G. Montgomery. 1984. Arthropods from the canopy of inundated and terra firme forests near Manaus, Brazil, with critical considerations on the pyrethrum-fogging technique. Studies Neotropical Fauna and Environmental 19: 223-236.

Adis, J.; M. I. Marques \& K. L. Wantzen. 2001. First observations on the survival strategies of terricolous arthropods in the northern Pantanal wetland of Brazil. Andrias 15: 127-128.

Adis, J.; W. Paarmann; C. R. V. Fonseca \& J. A. Rafael. 1997. Knockdown efficiency of natural pyrethrum and survival rate of living arthropods obtained by canopy fogging in Central Amazonia. p. 67-81. In: N. E. Stork; J. Adis \& R. K. Didham (eds.). Canopy Arthropods. London, Chapman \& Hall, 567 p.

Adis, J.; Y. Basset; A. Floren; P. M. Hammond \& K. E. Linsenmair. 1998a. Canopy fogging of an overstory tree-recommendations for standardization. Ecotropica 4: 93-97.

Adis, J.; A. Y. Harada; C. R. V. Fonseca; W. Paarmann \& J. A. Rafael. 1998b. Arthropods obtained from the Amazonian tree species "Cupiuba" (Goupia glabra) by repeated canopy fogging with natural pyrethrum. Acta Amazônica 28: 273-283.

Allison, A.; A. Samuelson \& S. E. Miller. 1993. Patterns of beetle species diversity in New Guinean rainforest as revealed by canopy fogging: preliminary findings. Selbyana 14: 16-20.

Allison, A.; A. Samuelson \& S. E. Miller. 1997. Patterns of beetle species diversity in Castanopsis acuminatissima (Fagaceae) trees studied with canopy fogging in mid-montane New Guinea rainforest, p. 224-236. In: N. E. Stork; J. Adis \& R. K. Didham (eds.). Canopy Arthropods. London, Chapman \& Hall, 567 p.

Basset, Y. 1991. The seasonality of arboreal arthropods foraging within an Australian rain forest tree. Ecological Entomology 16: 265-278.

Basset, Y. 2001. Invertebrates in the canopy of tropical forests: how much do we really know?, p. 87-107. In: K. E. Linsenmair; A. J. Davies; B. Fiala \& M. R. Speight (eds.). Tropical forest canopies: ecology and management. London, Kluwer Academic Publishers, Dordrecht, $370 \mathrm{p}$.

Basset, Y.; N. D. Springate; H. P. Aberlenc \& G. Delvare 1997. A review of methods for sampling arthropods in tree canopies In: N. E. Stork; J. Adis \& R. K. Didham (eds.). Canopy Arthropods. London, Chapman \& Hall, 567 p.

Basset, Y.; V. Novotny; S. E. Miller \& R. L. Kitching. 2003. Arthropods 
of tropical forests. Spatio-temporal dynamics and resource use in the canopy. Cambridge University Press, Cambridge.

Da Silva, C. J.; K. M. Wantzen; C. Nunes-da-Cunha \& F. A. Machado. 2001. Biodiversity in the Pantanal wetland, Brazil, p. 187-215 In: G. Gopal; W. J. Junk \& J. A. Davis. (eds.). Biodiversity in wetlands: assessment, function and conservation. Vol 2, Backhuys, Leiden.

Davidson, D. W. 1997. The role of resource imbalances in the evolutionary ecology of tropical arboreal ants. Biological Journal Linnean Society 61: 153-181.

Davies, J. G.; N. E. Stork; M. J. D. Brendell \& S. J. Hine. 1997. Beetle species diversity and faunal similarity in Venezuelan rainforest tree canopies, p. 85-103. In: N. E. Stork; J. Adis \& R. K. Didham (eds.). Canopy Arthropods. London, Chapman \& Hall, 567 p.

Erwin, T. L. 1983a. Tropical forest canopies: the last biotic frontier Bulletin Entomological Society American 30: 14-19.

Erwin, T. L. 1983b. Beetles and other insects of tropical forest canopies at Manaus, Brazil, sampled by insecticidal fogging, p. 59-75. In: S. L. Sutton; T. C. Whitmore \& A. C. Chadwick. (eds.). Tropical forest canopies: ecology and management. London, Kluwer Academic Publishers, Dordrecht, 370 p.

Erwin, T. L. 1989. Canopy arthropod biodiversity: a chronology of sampling techniques and results. Revista Peruana de Entomologia 32: 71-77.

Erwin, T. L \& J. C. Scott. 1980. Seasonal and size patterns trophic structure, and richness of Coleoptera in the tropical arborea ecosystem: the fauna of the tree Luehea seemannii Triana and Planch in the Canal Zone of Panama. Coleopterists Bulletin 34: $305-322$.

Farell, B. D. \& T. L. Erwin. 1988. Leaf-beetle community structure in an Amazonian rainforest canopy, p. 73-87. In: P. Jolivet; E. Petitpierre \& T. H. Hsiao (eds.) Biology of Chrysomelidae. Kluwer, Dordrecht.

Floren, A. \& K. E. Linsenmair. 1997. Diversity and recolonization dynamics of selected arthropod groups on different tree species in a lowland rainforest in Sabah, Malaysia with special reference to Formicidae, p. 344-381. In: N. E. Stork; J. Adis \& R. K. Didham (eds.). Canopy Arthropods. London, Chapman \& Hall, 567 p.

Floren, A. \& K. E. Linsenmair. 1998a. Non-equilibrium communities of Coleoptera in trees in a lowland rain forest of Borneo. Ecotropica 4: 55-67.

Floren, A. \& K. E. Linsenmair. 1998b. Diversity and recolonization of arboreal Formicidae and Coleoptera in a lowland rain forest in Sabah, Malaysia. Selbyana 19: $155-161$.

Hammond, P. M. 1990. Insect abundance and diversity in the DumogaBone National Park, N. Sulawesi, with special reference to the beetle fauna of lowland rain forest in Toraut region, p. 197-254. In: W. J. Knigt \& J. D. Holloway (eds.). Insects and the rain forest of South East Asia (Wallacea). The Royal Entomological Society of London.

Hammond, P. M.; R. L. Kitching \& N. E. Stork. 1996. The composition and richness of the tree-crown Coleoptera assemblage in an Australian subtropical forest. Ecotropica 2: 99-108.

Hammond, P. M.; N. E. Stork \& M. J. D. Brendell. 1997. Tree-crown beetles in context: a comparison of canopy and other ecotone assemblages in a lowland tropical forest in Sulawesi, p. 184-223. In: N. E. Stork; J. Adis \& R. K. Didham (eds.). Canopy Arthropods. London, Chapman \& Hall, $567 \mathrm{p}$.

Harada, A. Y. \& J. Adis. 1997. The ant fauna of tree canopies in Central Amazonia: a first assessment, p. 382-400 In: N. E. Stork J. Adis \& R. K. Didham (eds.). Canopy Arthropods. London, Chapman \& Hall, 567 p.

Harada, A. Y. \& J. Adis. 1998. Ants obtained from trees of "Jacareuba" (Calophyllum brasilense) forest plantation in Central Amazonia by canopy fogging: first results. Acta Amazônica 28: 309-318.

Hurtado-Guerrero, J. C.; C. R. V. Fonseca; P. M. Hammond \& N. E. Stork. 2003. Seasonal variation of canopy arthropods in Central Amazon, p. 170-175. In: Y. Basset; V. Novotny; S. E. Miller \& R. L. Kitching (eds.). Arthropods of tropical forests. Spatiotemporal dynamics and resource use in the canopy. Oxford University Press, Oxford.
Jolivet, P. 1992. Insects and plants: parallel evolution and adaptations. Flora \& Fauna Handbook 2. Sandhill Crane Press, Gainesville.

Junk, W. J.; P. B. Bayley \& R. E. Sparks. 1989. The flood pulse concept in river-floodplain systems. In: D. P. Dodge (ed.). Proc Int Large River Symp (LARS). Can Spec Publ Fish Aquat Sci 106: 110-127.

Lawrence, J. F.; A. M. Hastings; M. J. Dallwitz; T. A. Paine \& E. J. Zurcher. 1999. Beetles of the World. A key and information system for families and subfamilies. Version 1.0 MS Windows. Melbourne, Australia. CSIRO Publishing.

Linsenmair, K. E.; A. J. Davies; B. Fiala \& M. R. Speight. 2001. Tropical forest canopies: ecology and management. Kluwer, Dordrecht.

Magurran, A. E. 1988. Ecological diversity and its measurement. Chapman \& Hall, London.

Marques, M. I.; J. Adis; C. Nunes-da-Cunha \& G. B. Santos. 2001. Arthropod biodiversity in the canopy of Vochysia divergens Pohl (Vochysiaceae), a forest dominant in the Brazilian Pantanal. Studies Neotropical Fauna and Environment 36: 205-210.

Nascimento, M. T. \& C. Nunes-da-Cunha. 1989. Estrutura e composição florística de um Cambarazal no Pantanal de Poconé-MT. Acta Botânica Brasilica 3: 3-23.

Ribeiro, S. P. \& V. K. Brown. 1999. Insect herbivory in tree crowns of Tabebuia aurea and T. ochracea (Bignoniaceae) in Brazil: contrasting the cerrado with the "Pantanal Mato-grossense". Selbyana 20: $159-170$.

Samways, M. J. 1994. Insect Conservation Biology. Chapman \& Hall, London.

Santos, G. B.; M. I. Marques; J. Adis \& C. R. Musis. 2003. Artrópodos associados à copa de Attalea phalerata Mart. (Arecaceae), na região do Pantanal de Poconé-MT. Revista Brasileira de Entomologia 47: $211-224$.

Shmida, A. \& M. R. Wilson. 1985. Biological determinants of species diversity. Journal of Biogeography 12: 1-20.

Stork, N. E. 1988. Insect diversity: facts, fiction and speculation. Biological Journal Linnean Society 35: 321-337.

Stork, N. E. 1991. The composition of arthropod fauna of Bornean lowland rain forest trees. Journal Tropical Ecology 7: 161-180.

Stork, N. E. \& M. J. D. Brendell. 1990. Variation in the insect fauna of Sulawesi trees with season, altitude, and forest type, p. 173-190. In: W. J. Knight \& J. D. Halloway (eds.). Insects in the rain forests of South East Asia (Wallacea). The Royal Entomological Society of London, London.

Stork, N. E. \& M. J. D. Brendell. 1993. Arthropod abundance in lowland rain forest of Seram, p. 115-130. In: I. D. Edwards; A. A. MacDonald \& J. Proctor (eds.). Natural history of Seram: Malukku, Indonesia. Intercept, Andover.

Stork, N. E. \& P. M. Hammond. 1997. Sampling arthropods from treecrowns by fogging with insecticides: lessons from studies of oak tree beetle assemblages in Richmond Park (UK), p. 3-27. In: N. E. Stork; J. Adis \& R. K. Didham (eds.). Canopy Arthropods. London, Chapman \& Hall, $567 \mathrm{p}$.

Stork, N. E.; J. Adis \& R. K. Didham. 1997. (eds.). Canopy arthropods. London, Chapman \& Hall, 567 p.

Tobin, J. E. 1991. A neotropical rain forest canopy ant community: some ecological considerations, p. 536-538. In: C. R. Huxley \& D. F. Cutler (eds.). Ant-plant interactions. Oxford Univ Press, Oxford.

Tobin, J. E. 1995. Ecology and diversity of tropical forest canopy ants, p. 129-147. In: M. D. Lowman \& N. M. Nadkarni (eds.). Forest canopies. Academic Press, London.

Wagner, T. 1997. The beetle fauna of different tree species in forests of Rwanda and East Zaire, p. 169-183. In: N. E. Stork; J. Adis \& R. K. Didham (eds.). Canopy Arthropods. London, Chapman \& Hall, 567 p.

Wagner, T. 2000. Influence of forest type and tree species on canopydwelling beetles in Budongo forest, Uganda. Biotropica 32: $502-$ 514 .

Wilson, E. O. 1987. The arboreal ant fauna of Peruvian Amazon forests: a first assessment. Biotropica 19: 245-251.

Zar, J. H. 1974. Biostatistical analysis. Prentice Hall, Upper Saddle River. 